IZA DP No. 7645

Poverty, Labour Markets and Trade Liberalization in Indonesia

Krisztina Kis-Katos

Robert Sparrow

September 2013 


\title{
Poverty, Labour Markets and Trade Liberalization in Indonesia
}

\author{
Krisztina Kis-Katos \\ University of Freiburg \\ and IZA \\ Robert Sparrow \\ Australian National University \\ and IZA
}
Discussion Paper No. 7645
September 2013

\author{
IZA \\ P.O. Box 7240 \\ 53072 Bonn \\ Germany \\ Phone: +49-228-3894-0 \\ Fax: +49-228-3894-180 \\ E-mail: iza@iza.org
}

\begin{abstract}
Any opinions expressed here are those of the author(s) and not those of IZA. Research published in this series may include views on policy, but the institute itself takes no institutional policy positions. The IZA research network is committed to the IZA Guiding Principles of Research Integrity.

The Institute for the Study of Labor (IZA) in Bonn is a local and virtual international research center and a place of communication between science, politics and business. IZA is an independent nonprofit organization supported by Deutsche Post Foundation. The center is associated with the University of Bonn and offers a stimulating research environment through its international network, workshops and conferences, data service, project support, research visits and doctoral program. IZA engages in (i) original and internationally competitive research in all fields of labor economics, (ii) development of policy concepts, and (iii) dissemination of research results and concepts to the interested public.
\end{abstract}

IZA Discussion Papers often represent preliminary work and are circulated to encourage discussion. Citation of such a paper should account for its provisional character. A revised version may be available directly from the author. 


\section{ABSTRACT}

\section{Poverty, Labour Markets and Trade Liberalization in Indonesia}

We measure the effects of trade liberalization over the period of 1993-2002 on regional poverty levels in 259 Indonesian regions, and investigate the labour market mechanisms behind these effects. The identification strategy relies on combining information on initial regional labour and product market structure with the exogenous tariff reduction schedule over four three-year periods. We find that poverty reduced more in regions that were more strongly exposed to import tariff liberalization. Among the potential channels behind this effect, we highlight the formalization of the unskilled labour force and structural reallocation of labour. We also show that job formation and increases in unskilled wages were related to reductions in import tariffs on intermediate goods and not to reductions in import tariffs on final outputs. These results point towards increasing firm competitiveness as a driving factor behind the beneficial poverty effects.

JEL Classification: J13, O24, O15

Keywords: $\quad$ trade liberalization, labour markets, poverty, Indonesia

Corresponding author:

Krisztina Kis-Katos

Department of International Economic Policy

University of Freiburg

Platz der Alten Synagoge 1

79085 Freiburg

Germany

E-mail: krisztina.kis-katos@vwl.uni-freiburg.de

\footnotetext{
* This research has been supported by the German Federal Ministry of Education and Research (BMBF) under the grant No. 01UC0906. We would like to thank Hall Hill, Günther G. Schulze, and seminar participants at Bank Indonesia, the SMERU Research Institute and the Australian National University for useful comments and discussions. All errors are our own.
} 


\section{Introduction}

Trade liberalization has been widely expected to contribute substantially to poverty reduction in developing countries (e.g., the Doha Ministerial Declaration, WTO 2001). Under a more open trade regime, rising demand for unskilled labour could benefit poor workers by increasing workers' real wages (Stolper and Samuelson 1941) as well as creating more jobs in the formal economy. However, the growing body of micro-empirical evidence on the welfare implications of trade liberalization is not unequivocal. ${ }^{1}$ Short- to medium-run labour market effects of liberalized trade seem to be very much context specific and depend among others on the previous structure of protection (Attanasio et al. 2004), regional market access (Chiquiar 2008) as well as the degree of market flexibility. For example, overregulated local labour markets that inhibited the adjustment to structural change could explain the unfavourable regional poverty effects of trade reform in India (Topalova 2010). ${ }^{2}$ By contrast, bilateral trade liberalization between the US and Vietnam lead to clear reductions in Vietnamese rural poverty, potentially also due to higher labour market mobility (McCaig 2011). In this latter case, poverty reduction resulted from large improvements in the access to the US market whereas the loss of import protection to local markets was negligible. The question remains whether multilateral trade liberalization episodes, where the reduction in import protection and hence temporary job displacement plays a potentially larger role, could also benefit the poor.

Studies focusing on labour market and wage effects of tariff reductions present indirect evidence on potential effects of trade liberalization on poverty, again with mixed results. Reductions in protection and increased foreign competition generally seem to have increased skill premia in Latin America (e.g., Attanasio et al. 2004, Galiani and Sanguinetti 2003, Goldberg and Pavcnik 2005), although with some exceptions (e.g., Gonzaga et al. 2006 for Brazil). While most of these studies focus on formal manufacturing employment, Goldberg and Pavcnik (2003) also document an increase in informality in the sectors most exposed to tariff cuts in Colombia, although not in Brazil. These empirical findings of increases in skill premia and informality in Latin America suggest that it is less likely that trade would have had strongly favourable poverty effects in the region. However, contrasting evidence is presented by Porto (2006) who finds pro-poor distributional effects of Mercosur in Argentina through price changes and wage responses.

Indonesia offers an interesting case to study the poverty effects of trade liberalization. It is considerably more abundant in unskilled labour than large Latin American countries such as Mexico

\footnotetext{
${ }^{1}$ See e.g., Goldberg and Pavcnik (2007) and Winters et al. (2004) for surveys of the earlier literature.

${ }^{2}$ In a similar vein, tariff reductions in Brazil were associated with increases in urban poverty, which anecdotal evidence attributes to adjustment frictions and rising urban unemployment (Castilho et al. 2012).
} 
or Brazil and hence has a more pronounced comparative advantage in unskilled-labour intensive goods. In the period that we will study in this paper, Indonesia also had relatively flexible labour markets that could potentially restrict the adverse effects of trade reforms on poverty. Moreover, its vast geographic and economic diversity yields potentially large regional variation in the effects of trade liberalization.

With the completion of the Uruguay round in 1994, Indonesia committed itself to substantially lower its remaining tariff barriers across all tradable goods over the following ten years. The tariff reductions were concentrated in the hitherto most protected sectors and resulted in an overall convergence of sectoral protection levels; average import tariff lines decreased from around 17.2 percent in 1993 to 6.6 percent in 2002. During the same period, poverty rates also declined, although it is a priori unclear to what extent this decrease can be attributed to trade liberalization.

The existing empirical evidence suggests that trade liberalization could potentially explain a part of the reductions in Indonesian poverty during the nineties. Amiti and Cameron (2012) show that industrial skill premia (defined as the relative wage bill of nonproduction to production workers in manufacturing establishments with at least twenty employees) decreased as a response to tariff reductions. By distinguishing between tariffs on output and intermediate goods used by those firms they are also able to show that skill premia changed mostly because of improved firm competitiveness due to reductions in tariffs on intermediate goods. Kis-Katos and Sparrow (2011) document that child labour decreased faster in regions that were relatively more exposed to trade liberalization, with indirect evidence that this was driven by positive income effects for the poor. Descriptive evidence also shows the presence of ongoing structural change and reductions in wage inequality (Suryahadi 2003) as well as improvements in labour conditions (Robertson et al. 2009) over the same time period. However, this evidence, although suggestive, does not directly address the poverty effects of trade liberalization and the relative importance of the different channels for poverty reduction.

In this study we assess the causal effects of tariff reductions on poverty in Indonesian districts in the period of 1993 to 2002, and examine the role of labour markets in generating income effects from trade reforms. Our study extends the literature on the poverty effects of trade liberalization by studying the effects of tariff reductions in a geographically diverse Southeast-Asian country with large labour mobility. Using district pseudo-panel data, we find that tariff reductions reduce the depth and severity of poverty. 
In addition, our analysis focuses on the channels of labour market dynamics, job formalization, wages, job creation and displacement. With regard to wage effects and job creation, we are able to identify the regionally differential effects of tariffs on output and intermediate goods using firm level data (following Amiti and Cameron, 2012). We find that increased competitiveness of firms due to lower import tariffs on intermediate goods offers the main explanation for increases in manufacturing employment and wages, especially for low skilled labour. This contributes to the scant empirical evidence on the effects of trade liberalization on labour markets, in particular highlighting the differences in the mechanisms of liberalization affecting intermediate and output goods. $^{3}$

The next section presents the data sources for the pseudo-panel analysis and section 3 describes the context and trends in tariff reductions and poverty. Section 4 presents the identification strategy; the results follow in section 5 . Section 6 discusses caveats, considers potentially remaining sources of bias and provides a sensitivity analysis. Section 7 concludes.

\section{Data}

We measure the extent of trade liberalization by reductions in the average (unweighted) tariff lines in 19 tradable goods sectors for the years 1993, 1996, 1999, and 2002. ${ }^{4}$ The source of the tariff information is the UNCTAD-TRAINS database (retrieved through the WITS system of the World Bank). We combine this tariff data with information on the district level labour market structure before the tariff reform, based on the 1990 Indonesian Census. ${ }^{5}$ It provides the main sector of occupation for each individual in the sample at the 2-digit level. In order to combine tariff data with the information on labour market structure, we compute average tariffs at the same level of product aggregation as the available labour market data; we are thus able to distinguish between 5 subsectors in agriculture (plants and animals; forestry; hunting; sea fishery; fresh-water fishery), 6 subsectors in mining (coal; metal ore; stones; salt; minerals and chemicals; other mining) and 9 in manufacturing (food, beverage and tobacco; textile, apparel and leather; wood and products; paper

\footnotetext{
${ }^{3}$ Goldberg and Pavcnik (2003) assess the effects of trade liberalization on the informal sector in Brazil and Colombia. Autor, Dorn and Hanson (2012) look at job displacement in the US due to imports from China, while lacovone, Rauch and Winters (2013) find displacement effects in Mexico as a result of increased competition from China for its exports on US markets.

${ }^{4}$ Since tariff data is missing for the years 1994, 1997 and 1998, we base our analysis on four equally spaced time periods.

${ }^{5}$ We use a $1 \%$ random sample available for public use through the IPUMS system (Minnesota Population Center, 2011).
} 
and products; chemicals; non-metallic mineral products; basic metals; metallic products; other manufacturing).

Our primary source of household information is the annual national household survey, Susenas (Survei Sosial Ekonomi Nasional). This repeated cross-section survey is representative at the level of Indonesian districts. ${ }^{6}$ Poverty measures are derived from a comparison of monthly per capita household expenditures with province-specific urban/rural poverty lines (based on Suryahadi, Sudarno and Pritchett, 2003). Based on this, we calculate three poverty measures: the poverty headcount ratio ( $\mathrm{PO}$, the ratio of people living under the poverty line), the poverty gap ( $\mathrm{P} 1$, the aggregated income gap of the poor normalized by the total income needed to reach the poverty line), and the squared poverty gap (P2, depicting the depth of poverty, which is defined as the sum of squared individual deviations from the poverty line of those living below the poverty line, normalized by the squared value of the poverty line income).

We use additional information from Susenas to record whether individuals are active in the labour market and whether they are employed in the formal sector. All adults (aged 16 years or older) are considered to be active in the labour market if they report having a permanent job, having worked at least one hour during the week preceding the survey, or having been in search for work. Formal employment is defined as working for an employer with permanent workers, the government or a firm in the private sector. Because of changes in questionnaire design, we can consistently measure formality only until 1996. We also record the primary sector of work for each individual in the sample and distinguish between agriculture, mining, manufacturing and a number of service industries (utilities, construction, trade, transportation, financial and other services).

A second source of individual level information is the annual labour force survey, Sakernas (Survei Angkatan Kerja Nasional). This allows us to compute monthly wages, which are not available from the household surveys. Sakernas data are representative at the level of 27 provinces.

Information on the number of industrial workers and on total industrial wage payments in each district comes from the annual industrial census SI (Survei Industri) that includes all Indonesian firms operating with at least 20 employees. Additionally, we use the data on SI firms to describe the regional industrial structure, which enables us to generate alternative regional tariff exposure measures. Specifically, following Amiti and Konings (2007) and Amiti and Cameron (2012), we distinguish between the reduction in tariffs on industrial outputs and inputs, by generating a proxy of the regional sectoral input structure based on regional outputs and a national input-output-table.

\footnotetext{
${ }^{6}$ For calculating district level variables we use the population weights provided in Susenas.
} 
We use the latest national input-output table from the time period before the reforms, which distinguishes between 161 input and output sectors. The IO-table is based on the economic census (Sensus Ekonomi) of 1990, and has been compiled by Statistics Indonesia (BPS). We combine this information with the regional production structure derived from SI and our tariff variables, which allows us to distinguish 60 tradable sectors (see section 4.1 for more detail).

Information on migration flows across regions is derived from the intercensal survey Supas (Survei Penduduk Antar Sensus) from 1995, available through IPUMS (Minnesota Population Center, 2011). In order to incorporate migration data, we adjust the analyzed time frame to reflect the 5-year recollection period of Supas. Due to the lower number of districts covered in the intercensal survey, the analysis of migration refers to 203 districts only.

We use these various data sources to build a balanced pseudo-panel of Indonesian districts, which are classified as either rural districts (kabupaten) or municipalities (kota). Districts are practical units of analysis for assessing the poverty effects of trade liberalization as they are well defined geographic areas and key administrative units in Indonesia that reflect local labour markets. During the period under study, new districts emerged as a result of district splits. We deal with these splits by applying the 1993 district definition frame. ${ }^{7}$ Some of the districts had to be dropped from the sample. After excluding peripheral regions with incomplete or missing socio-economic data (all districts in the provinces of Aceh, Maluku and Irian Jaya) as well as East Timor (which gained independence in 1999) we are left with a balanced panel of 259 districts.

\section{Descriptive trends}

Indonesia started to liberalize its trade regime from the mid-1980s, involving a first reduction in tariff lines and a slow tariffication of nontariff barriers (Basri and Hill 2004). These reforms were accompanied by reforms of fiscal policy, tax reforms and financial deregulation. The second wave of trade liberalization started in the beginning of the 1990s. By the end of the Uruguay round, Indonesia entered formal multilateral agreements to apply binding tariff ceilings of maximum $40 \%$ on 95\% of its products (up from 9\% of binding tariff ceilings before) (WTO 1998). In May 1995 Indonesia announced a unilateral tariff reduction schedule, to be accomplished by 2003 , that went even further than its WTO obligations (WTO 1998).

\footnotetext{
${ }^{7}$ Districts splits followed almost entirely sub-district boundaries within the relevant district, and did not affect borders with neighboring districts. See Fitrani, Hofman and Kaiser (2005) for a more complete account of this process. Statistics Indonesia maintains a full list of district codes over time (see http://www.bps.go.id/ mstkab/mfkab_03_09.pdf).
} 
Figure 1 shows the reduction in average unweighted effectively applied tariff lines across the 1990s: on average, tariff lines reduced from $17.2 \%$ in 1993 to $6.6 \%$ in 2002 . Tariff reductions were the largest preceding the formation of the WTO but a second substantial wave of tariff reductions followed in the post monetary crisis period as part of the IMF conditionality package, starting with 1999. Table 1 shows the detailed evolution of the tariff schedule for 20 major tradable sectors, which are defined according to a concordance of tariff information and census labour market data. These tariff reductions happened across the board and were the highest in those industries that started with the highest original tariff levels, due to the prevalence of firm-specific protection measures in Indonesia (Basri and Hill 1996). In particular, some manufacturing sectors (such as wood, textiles or other manufacturing) with high initial average levels of protection saw average tariff rates reduce to below $10 \%$ by 2002 . The food sector is an exception (with an average tariff of $12.6 \%$ in 2002), partly because of tariffication and later exemption of alcoholic beverages.

The period before the economic crisis was also characterised by high labour market flexibility and a highly elastic supply of unskilled labour (Manning 2000). The early 1990s saw a continued shift from agricultural towards urban employment, an expanding service sector and the growth of an exportoriented economy. These structural changes were accompanied by steadily decreasing poverty rates. Suryahadi, Suryadarma and Sumarto (2009) argue that the growth in urban services was a powerful driving force behind these poverty reductions. Increases in inequality during this period suggest, however, that the beneficial effects of the reforms were not concentrated on the very poor (Miranti 2010). At the same time, labour regulation started to tighten somewhat, with rising minimum wages and extensions of social security coverage.

The $1997 / 98$ crisis had its roots in a monetary contagion leading to a large outflow of foreign capital, currency depreciation, as well as short-term agricultural price hikes. This also led to a sudden increase in expenditure poverty and a temporary restructuring of the labour force towards subsistence production in agriculture. The crisis' impacts were geographically clustered (Java being most strongly hit), but did not differ considerably between rural and urban regions or by the initial levels of poverty (Wetterberg, Sumarto and Pritchett 2001). The extent of expenditure poverty peaked around November of 1998 and declined sharply afterwards, with a quick recovery in consumption growth (Suryahadi, Sumarto and Pritchett 2003).

\section{Methods}

Following Topalova (2010), several recent studies identify regionally differential effects of trade liberalization by distinguishing between different levels of regional exposure to trade based on the 
pre-reform labour market structure of the region (Kovak 2010, McCaig 2011, Fukase 2013, Castilho et al. 2012). The advantage of this method is that it does not only focus on the manufacturing sector or formal employment but measures the effects of trade liberalization at the household level. To define tariff exposure, it uses the labour structure of local residents based on household surveys, irrespectively of the specific place and geographic location of their work, and hence focuses on tariff effects important for local residents. The main poverty measures are derived from household expenditure surveys, which capture the overall extent of regional poverty and offer a superior source for poverty analysis. We complement this household based information with data from firm and labour market surveys in order to investigate the labour market mechanisms that are behind these poverty effects.

\subsection{Measuring tariff exposure at district level}

Our empirical strategy applies a measure of district tariff exposure that combines variation over time in nationally determined import tariffs with district specific labour shares in the initial pre-reform period:

$$
\operatorname{Tariff}_{k t}=\sum_{h=1}^{H}\left(\frac{L_{h k, 1990}}{L_{k, 1990}} \times \operatorname{Tariff}_{h t}\right)
$$

The tariff exposure measure of district $k$ in year $t, \operatorname{Tariff}_{k t}$, is calculated as a weighted average of sectoral import tariffs of each sector $h$. The weights are given by the relative share of the employment of sector $h\left(L_{h k, 1990}\right)$ in the total labour force of district $k\left(L_{k, 1990}\right)$, measured at an initial time period, in 1990.

This tariff exposure measure is implicitly affected by the size of the non-tradable sector as weights are normalized by the size of the total labour force of the district, and not only by the labour force employed in tradable sectors. This is in line with the main definition applied by McCaig (2011) but deviates from the methods employed by Topalova (2010) or Kovak (2010). Topalova (2010) instruments tariffs weighted by labour market shares that include nontradables with tariffs weighted by labour market shares in tradable sectors only. Kovak (2010) argues that one should drop the nontradables sector altogether since there should be a perfect pass-through effect from tradable price changes to nontradable prices. However, the regional size of the nontradable sectors will matter if the pass-through is imperfect. Under robustness checks in section 6.2 we address the sensitivity of our results to the exclusion of the nontradable sectors from the weighting scheme. 
In addition to our main tariff exposure based on the labour market structure, we also compute regional tariff exposure measures weighted by the regional industrial structure. This enables us to identify the effects of tariff changes on the wage bill and employment of regionally important firms. These alternative tariff measures are based on the output structure of formalized firms with at least 20 employees (from SI, the industrial census). Following the insights of Amiti and Konings (2007) and Amiti and Cameron (2012), we distinguish between tariffs on firm output and tariffs on the intermediate inputs used by firms. While output tariffs can be expected to affect firm productivity through increased competition on the output markets, lower input tariffs have a more direct productivity enhancing role by rendering inputs cheaper (Amiti and Konings 2007). Input (but not output) tariff reductions have also been shown to go along with reductions in industrial skill premia (Amiti and Cameron 2012).

In our application, we redefine the product level tariff measures to once again capture regional differences in tariff exposure:

$$
\text { OutputTarif } f_{k t}=\sum_{s=1}^{S}\left(\frac{Q_{s k, 1993}}{Q_{k, 1993}} \times \text { Tariff }_{s t}\right)
$$

The output tariff measure weights national tariffs in sector $s$ at year $t$ by the industry's initial share in region $k$ 's industrial output, $Q_{s k, 1993} / Q_{k, 1993}$, as recorded in the industrial census in the initial year 1993. ${ }^{8}$

For computing the input tariff, we rely on a national input-output table from 1990 to generate a measure of regional exposure to input tariffs based on the regional sectoral structure:

$$
\text { InputTariff }_{k t}=\sum_{s=1}^{S}\left(\frac{Q_{s k, 1993}}{Q_{k, 1993}} \times \sum_{j=1}^{J}\left(\frac{M_{j s, 1990}}{M_{s, 1990}} \times \text { Tariff }_{j t}\right)\right)
$$

For this, we weight the tariff on each input good $j$ in year $t$ by the initial share of the $j$-th industry among the inputs of any output sector $s, M_{j s, 1990} / M_{s, 1990}$. We once again aggregate these input tariff measures across all output producing industries of the region, which are then weighted by the output industry's initial relative regional importance, $Q_{s k, 1993} / Q_{k, 1993}$. Since our input-output data does not vary across regions, we have to assume that the national structure of inputs adequately describes the regional input structures, at least on average. By using a pre-reform input-output table we can ensure that tariff induced shifts in the industrial structure are not reflected in the measure.

\footnotetext{
${ }^{8}$ After taking tariff and input-output table concordances into account, we are able to distinguish between $S=60$ different tradable output industries.
} 
These tariff measures reflect the presence of nontradable goods to a different extent. The output tariff is weighted by tradable goods only since all industrial products included in the weighting scheme are tradable. The input tariff takes nontradable inputs into consideration implicitly, by including nontradable goods in the total sectoral inputs $M_{s, 1990}$.

\subsection{Empirical specification and identification}

The primary interest of our study lies in understanding how regional exposure to tariff reductions affected regional levels of poverty. According to the neoclassical theory of comparative advantage, reduction in trading costs in a labour abundant economy can be expected to increase specialization in the production of unskilled labour intensive goods, which should lead to relative improvements in the wages of the less skilled population. Hence, the poverty reducing effects of international trade will be primarily transmitted through labour market mechanisms. In order to investigate these mechanisms, we focus not only on poverty measures but also on labour market outcomes. More specifically, we test whether tariff reductions affect sector mobility, labour market participation and formalization, job creation and wages.

Our main estimating equation takes the following first difference specification:

$$
\Delta y_{k t}=\alpha+\beta \Delta \operatorname{Tariff}_{k t}+\Delta X_{\mathrm{kt}}^{\prime} \gamma+I_{k}^{\prime} \theta+\lambda_{r t}+\Delta \varepsilon_{k t}
$$

where $y_{k t}$ denotes the district level dependent variables (poverty rates, labour and formalization shares, average or total wages and employment). $X_{k t}$ is a vector of time variant control variables (share of rural population, share of working population aged 16-60, adult (20+) literacy rates, minimum wages). The vector of initial conditions, $I_{k}$, includes the 1990 labour shares in the region that are used as tariff weights, aggregated to one digit sectors, the 1990 rural population shares, and, in some specifications, the initial levels of the dependent variable. Time and island interaction terms, $\lambda_{r t}$, are included to control for regions specific time effects. The main islands are defined as Java, Sumatra, Kalimantan, Sulawesi, while the remaining smaller islands are grouped together.

The difference specification addresses the potentially endogenous nature of the components in the tariff exposure measure. First, the potential bias due to endogenous tariff setting at the national level is eliminated by controlling for national variation over time and by considering only withindistrict variation. Second, by taking first differences and removing district fixed effects, we purge any bias due to unobserved heterogeneity that might be introduced by the initial district sectoral structure in employment and industry output. Moreover, the district labour and industry output 
shares by sector are taken at 1990 values and are therefore not directly influenced by district poverty profiles and labour market developments in 1993.

This approach relies on the indentifying assumption that there are no unobserved time variant confounders. This assumption will be violated if poverty trends and labour market dynamics are related to the initial sectoral composition of district economies. The most relevant potential confounding trends include structural change, overall economic development and social policies. Structural change involves a gradual shift from agriculture to manufacturing and service sectors. The extent and speed of such structural change may vary by the initial size of the agricultural sector and the share of the population living in rural areas. Changes in poverty incidence will also be driven by overall economic development as well as targeted social policies. These may vary by initial levels of poverty (due to convergence or policy targeting) and by local economic structure.

We deal with these potential confounding trends by adding controls for initial conditions: initial sectoral labour shares (measured at the one-digit level) as well as the share of rural population in 1990. As an additional sensitivity check we include the 1993 value of the dependent variables (P0, P1 and P2) to proxy for convergence and targeting. Finally, we conduct placebo tests. If confounding trends are driving our results, through initial labour shares, then we would expect that current poverty changes are correlated with future changes in local tariff exposure. The placebo tests consist of regressions of poverty changes, $\Delta \bar{y}_{k t}$, on changes in tariff exposure of the following period, $\Delta \operatorname{Tariff}_{k t+1}$, where the null of no confounding trends is rejected if the tariff coefficient is statistically significant.

The 1997/98 financial crisis poses a potential problem for our empirical strategy. Although our observation period only includes pre- and post-crisis years (1996 and 1999), the post-crisis recovery remains a potentially confounding effect. We deal with this concern in two ways: we include in all regressions island-year fixed effects that distinguish between five main geographic units and allow the crisis effects to vary across the regions. Given the empirical evidence on the strong geographical clustering of the poverty effects of the crisis (Wetterberg, Sumarto and Pritchett 2001), we are able to capture a part of the crisis effects already through this strategy. Additionally, we also re-estimate our models for separate, shorter time periods, pre-crisis (1993-1996) and for the post-crisis period (1999-2002). 


\section{Results}

\subsection{Poverty}

The general effects of tariff reductions on our three poverty measures (P0, P1 and P2) for different specifications are shown in Table 3. There is a positive correlation between the poverty head count and tariff exposure, implying that tariff reduction is associated with a reduction in poverty. This relationship also holds after controlling for year-island fixed effects and time variant controls. However, once we control for initial conditions (labour force structure and rural population size), the coefficient reduces by half and is no longer statistically significant.

For both the poverty gap and poverty severity, on the other hand, the estimates are robust to including initial conditions. Tariff reductions seem to have contributed to alleviating the depth of poverty in Indonesia and have been particularly favourable for the very poor. A percentage point reduction in tariff exposure is associated with a decrease of the poverty gap equivalent to 0.6 percent of the poverty line, and a decrease of poverty severity by 0.003 .

Column (4) in Table 3 presents a specification where we control for initial levels of the dependent variable, to assess whether initial poverty is associated with differential parallel trends that may confound our estimates. We find no evidence of this, as the results are robust to including these variables. Since we prefer not to include lagged levels of the dependent variable in a fixed effects specification, we omit these in the remainder of the analysis.

Table 4 disaggregates the results from our preferred specification (column 3 in Table 3 ) by skill level of the household head. We distinguish between three educational categories: household heads with at most primary education, those with completed junior secondary education, and those with at least a completed senior secondary education. The reductions in poverty depth and severity seem to be driven by low- and medium skilled labour, although the estimates for the share of population where the household head has at most primary education is not as precise as those for the middleskilled. For the high skilled population the estimates are small and not statistically significant, presumably partly due to the relatively lower incidence of poverty in this group.

\subsection{Labour market dynamics}

As documented in Table 5, tariff reduction is associated with increased formal sector employment, which measures the share of the active population employed either by the government, a private sector employer or an employer who has permanent workers. This effect is driven by an increasing formalization of the labour force among low and middle skilled workers whereas there is no similar 
effect among higher skill workers. ${ }^{9}$ As formal sector jobs are usually generating larger and less volatile (more secure) incomes, job formalization could have considerably contributed to the favourable poverty effects of trade liberalization. By contrast, we find no notable effects on labour market activity, which suggests that income effects from trade liberalization have been induced mainly through job creation in the formal sector, and low skilled labour moving from informal to formal sector jobs.

Table 6 presents the effects of exposure to trade liberalization on the regional distribution of the broad sector of employment. Tariff reductions do not seem to have lead to much mobility between tradable and non-tradable sectors, at least in aggregate terms. We find no evidence that changes in the share of workers employed in agriculture, mining, and manufacturing could be explained by trade liberalization. This is despite the fact that mobility between sectors in the study period was high (Suryahadi 2003). The above result however does not preclude the possibility of finer-scale migration across different parts of these more broadly defined sectors. Moreover, we see some evidence for reallocation of labour across the various nontradable sectors: among low skilled workers tariff reduction has lead to decreasing labour shares in construction and increasing shares in trade and financial services. We also see an increased share of financial services among the high skilled workers, at the expense of the utilities sector.

\subsection{Firms: wages and workers}

Previous studies document that trade liberalization in Indonesia has improved firm productivity (Amiti and Konings 2007) and increased the relative magnitude of the wage bill paid by manufacturing firms to lower as opposed to high skilled workers (Amiti and Cameron 2012). These effects were in particular due to decreases in import tariffs on intermediate production goods used by the firms. These findings suggest that direct improvements in the profitability of local firms might also help explaining the observed favourable income effects to the poor. In order to investigate this channel more closely, we extend the analysis to the total wage bill of large manufacturing firms in the region and total employment by those firms. We use the same manufacturing firm data as the two studies above and also differentiate between the effects of tariffs for intermediate inputs and production outputs, but run the analysis at the level of the regional economies in order to retain comparability with our previous results.

Table 7 shows that both the total manufacturing wage bill and total employment increase with a decrease in tariffs on product groups that are relevant as input goods for the regional production: a

\footnotetext{
${ }^{9}$ These estimates are available only for the time period 1993 to 1996 because we are not able to construct a time consistent variable for formal labour due to changes in the Susenas questionnaire in both 1999 and 2002.
} 
one percentage point reduction in input tariffs increases the average wage bill by 8.2 percent and total employment by 4.7 percent. ${ }^{10}$ By contrast, we do not find evidence that reductions in tariffs that are relevant to the structure of the regional economic output affect employment or the wage bill. Together with the findings by Amiti and Cameron (2012), this seems to suggest that trade liberalization has led to job creation in the formal manufacturing sector, in particular for low skilled workers. Moreover, the total wage bill has increased relatively more strongly due to tariff reductions than total employment, suggesting an average increase in wages or at least an increase in per capita work intensity.

Since the SI data does not provide information on the hours worked, we cannot distinguish between these two potential margins of adjustment. However, we can look at average wages at province level, which are collected by the labour force survey (Sakernas). As the number of provinces is considerably lower than the number of districts (23 as compared to 259), this is admittedly a much cruder measure, but can be disaggregated by education level.

The province level estimates confirm that wages have increased as a result of tariff reductions for intermediate inputs, while no significant effects could be observed from changes in output tariffs. A one percentage point reduction in input tariffs reduced average hourly wages by 2.4 percent. Moreover, the effects seem larger for relatively low skilled workers, although the estimates are imprecise.

\section{Sensitivity analysis and caveats}

\subsection{Robustness of poverty results to confounding trends and definitions of tariff measures}

Our specifications address the issue of confounding trends in poverty that are related to the original economic/labour market structure of the districts by controlling for initial labour shares of the main sectors as well as initial rural shares in the districts. In addition, Table 8 presents placebo test results from regressions of current reductions in poverty on future reductions in our tariff measure (using a one-period lead). Significant effects of future tariff changes on current outcomes would mean that our results are still biased by confounding trends that drive poverty reduction and are imperfectly controlled for by the initial conditions. We do not find any evidence for this problem: the future tariff coefficients are small and not statistically significant, irrespective of the specification. ${ }^{11}$

\footnotetext{
${ }^{10}$ In our sample, the input tariff measure decreased on average by 1.8 percentage points per period.

${ }^{11}$ We also conduct placebo tests for a two-period lead, that is, we regress 1993-1996 poverty changes on 1999-2002 changes in tariff exposure. These tests provide similar results.
} 
In our analysis we define the tariff measures based on the labour shares of the total regional economy, including both traded and non-traded sectors. However, some studies propose a different approach and argue that labour shares should be calculated only with respect to the size of the tradable sectors (e.g. Topalova 2011, Kovak 2010).

Table 9 contrasts our results to those using the alternative weighting scheme. Column (1) reproduces our previous results, column (2) shows poverty results based on tradable sector weights only, whereas column (3) splits the sample and presents results based on tradable sector weights in those districts where the labour force share of the non-tradable sector in 1990 was below the median of $33 \%$. These results show that the poverty effects of tariff reductions are driven by the effects of trade liberalization in districts where the tradable sector is large enough such that poverty effects can be measured with precision at district level. The tariff exposure measure that excludes the non-tradable sector does not pick up any poverty effects, but when we focus only on the $50 \%$ of districts with a relatively small non-tradable sector, we find results similar to those for the tariff exposure that includes the non-tradable share. These results seem to suggest that the perfect passthrough assumption holds only if the size of the tradable sector is sufficiently large.

\subsection{The monetary crisis and differential effects over time}

The Southeast Asian monetary crisis of 1997/98 constitutes a potentially important confounding factor during the analysed time period, especially since it has lead to a short-time spike in relative food prices and sharp short-term increases in poverty. Since the effects of the crisis were strongly geographically clustered, the inclusion of island-year fixed effects deals partly with this problem. However, in order to exclude that the crisis confounds our estimates, we repeat our main specifications, excluding the crisis years, for the pre-crisis and post-crisis periods separately.

Table 10 show the results by time period. The estimates for the poverty gap and poverty severity are consistent for the 1999-2002 period but not precise, presumably due to the smaller sample size. However, we find no evidence for the 1993-1996 period. Tariff reductions increased total wages paid by manufacturing firms during both periods, but the effect is twice as strong in 1999-2002 as in 1993-1996. However, we only see an increase in total firm employment in 1993-1996. The results for province average hourly wages suggest that these effects also translated into higher wages, especially after the crisis. Moreover, the post-crisis wage increase was especially strong for low skilled workers, while pre-crisis effects on wages were mainly observed for workers with junior secondary schooling. These results are consistent with the findings for poverty outcomes: while tariff 
reductions seem to have affected household incomes through wage increases and job creation, the poorest segments of the population benefitted especially in the post crisis period.

\subsection{Migration}

Migration can offer a further channel of transmission for the effects of trade liberalization by measuring the extent of regional reallocation of labour; at the same time it can also confound our poverty estimates over time. In order to test for a correlation between tariff reductions and migration, Table 11 relates across-district migration between 1990 and 1995 to changes in district tariff exposure over the same time period. We focus on the first part of our period of analysis since migration flows preceding 2000 were strongly affected by the economic crisis as well as highintensity conflict. ${ }^{12}$ The available data do not allow us to identify causal effects of tariff reductions on internal migration. Nevertheless, we do find descriptive evidence that the direction of internal migration flows is towards districts with relatively strong exposure to tariff reductions, controlling for province fixed effects (for 25 provinces), district population size and labour shares by sector.

The results show no considerable association between regional exposure to tariff reductions and emigration from the district for the period of 1990-1995. That is, we do not find evidence for displacement effects due to structural change leading to out-migration of workers. At the same time there is a statistically significant negative relationship between changes in tariff exposure and immigration, especially for lower skilled workers. Thus, if anything, exposure to trade liberalization has acted as a pull factor for migration. One possible explanation behind this effect is the creation of new low skilled jobs that lead to increased immigration of low wage workers. These results also imply that we might underestimate the extent of poverty reducing effects of trade, since it is especially lower skilled and hence more likely poor workers who migrate into the regions more affected by structural change. These migration inducing effects of tariff changes are in line with the overall findings of McCaig (2011) on Vietnamese migration following the bilateral trade agreement with the US, although unlike in Indonesia, in Vietnam migration increased for all skill categories, with somewhat higher effects on the higher skilled.

\section{Conclusion}

We have examined the effects of trade liberalization in Indonesia from 1993 to 2002 on poverty levels in 259 Indonesian districts and the role of labour market as channel for these effects. During this period, Indonesia reduced its tariff barriers across all tradable sectors, with average import

\footnotetext{
${ }^{12}$ Repeating the same regressions for the period of 1995 to 2000 shows no significant correlation between exposure to tariff reductions and cross-regional migration.
} 
tariffs decreasing from 17.2 percent in 1993 to 6.6 percent in 2002. This period also saw a strong reduction in poverty, despite a temporary setback from the 1997/1998 economic crisis.

The identification strategy relies on combining information on initial regional labour and product market structure with the exogenous tariff reduction schedule over three-year intervals. The results are robust to specification and controlling for initial conditions in labour market structure, and placebo tests show no evidence that confounding trends are affecting the estimates.

Our results suggest that trade liberalization has contributed partially to poverty reduction in Indonesia by increasing incomes for the poorest segment of the population. While we do not see substantial effects on the poverty head count, we do find that tariff reductions led to a statistically significant reduction of the depth and severity of poverty.

The driving mechanism behind these effects seems to be increasing firm competitiveness as a direct result of reductions in import tariffs on intermediate goods; whereas we see no evidence of displacement effects from increased foreign competition due to reductions in import tariffs on final outputs. Increased firm competitiveness in turn induced a further formalization of the labour force, job formation and wage increases for low- and medium skilled labour. These experiences with trade liberalization add caution to the current policy debate in light of the recent surge in protectionist tendencies in Indonesian trade and economic policies (Nehru 2013). 


\section{References}

Amiti, M. and Cameron, L. (2012): Trade liberalization and the wage skill premium: Evidence from Indonesia, Journal of International Economics, 87(2): 277-287.

Amiti, M. and Konings, J. (2007): Trade liberalization, intermediate inputs and productivity: Evidence from Indonesia, American Economic Review, 97(5): 1611-1638.

Attanasio, O., Goldberg, P.K. and Pavcnik, N. (2004): Trade reforms and wage inequality in Colombia, Journal of Development Economics, 74(2): 331-366.

Autor, D.H., Dorn, D. and Hanson, G.H. (2012): The China syndrome: Local labor market effects of import competition in the United States, NBER Working Papers, No. 18054, National Bureau of Economic Research, Inc., Cambridge, Mass.

Basri, M.C. and Hill, H. (1996): The political economy of manufacturing protection in LDCs: An Indonesian case study, Oxford Development Studies, 24(3): 241-259.

Castilho, M., Menéndez, M. and Sztulman, A. (2012): Trade liberalization, inequality, and poverty in Brazilian states, World Development, 40(4): 821-835.

Chiquiar, D. (2008): Globalization, regional wage differentials and the Stolper-Samuelson Theorem: Evidence from Mexico, Journal of International Economics, 74(1): 70-93.

Fitrani, Hofman and Kaiser (2005): Unity in diversity? The creation of new local governments in de decentralizing Indonesia, Bulletin of Indonesian Economic Studies 41(1): 57-79.

Fukase, E. (2013): Export liberalization, job creation, and the skill premium: Evidence from the USVietnam Bilateral Trade Agreement (BTA), World Development, 41(C): 317-337.

Galiani, S. and Sanguinetti, P. (2003): The impact of trade liberalization on wage inequality: Evidence from Argentina, Journal of Development Economics, 72(2): 497-513.

Goldberg, P.K. and Pavcnik, N. (2003): The response of the informal sector to trade liberalization, Journal of Development Economics, 72(2): 463-496.

Goldberg, P.K. and Pavcnik, N. (2007): Distributional effects of globalization in developing countries, Journal of Economic Literature, 45(1): 39-82.

Gonzaga, G., Menezes Filho, N. and Terra, C. (2006): Trade liberalization and the evolution of skill earnings differentials in Brazil, Journal of International Economics, 68(2): 345-367.

lacovone, L., Rauch, F. and Winters, L.A. (2013): Trade as an engine of creative destruction: Mexican experience with Chinese competition, Journal of International Economics, 89(2): 379-392. 
Kis-Katos, K. and Sparrow, R. (2011): Child labor and trade liberalization in Indonesia, Journal of Human Resources, 46(4): 722-749.

Kovak, B.K. (2010): Regional labor market effects of trade policy: Evidence from Brazilian liberalization, RSIE Discussion Papers No. 606, Research Seminar in International Economics, University of Michigan, Ann Arbor, Michigan.

Manning, C. (2010): Labour market adjustment to Indonesia's economic crisis: Context, trends and implications, Bulletin of Indonesian Economic Studies, 36(1): 105-136.

McCaig, B. (2011): Exporting out of poverty: Provincial poverty in Vietnam and U.S. market access, Journal of International Economics, 85(1): 102-113.

Minnesota Population Center (2011): Integrated Public Use Microdata Series, International: Version 6.1 (Machine-readable database). Minneapolis: University of Minnesota.

Miranti, R. (2010): Poverty in Indonesia 1984-2002: The impact of growth and changes in inequality, Bulletin of Indonesian Economic Studies, 46(1): 79-97.

Nehru V. (2013): Survey of recent developments, Bulletin of Indonesian Economic Studies, 49(2):139166.

Porto, G.G. (2006): Using survey data to assess the distributional effects of trade policy, Journal of International Economics, 70(1): 140-160.

Robertson, R., Sitalaksmi, S., Ismalina, P. and Fitrady, A. (2009): Globalization and working conditions: Evidence from Indonesia. In Robertson, R., Brown, D., Gaelle, P and Sanchez-Puerta, M.L. (eds.): Globalization, wages, and the quality of jobs: Five country studies. Washington D.C.: World Bank: 203-236.

Stolper, W.F. and Samuelson, P.A. (1941): Protection and real wages, Review of Economic Studies, 9(1): 58-73.

Suryahadi, A. (2003): International economic integration and labor markets: The case of Indonesia, In Hasan, R. and Mitra, D. (eds.): The impact of trade on labor: Issues, perspectives, and experiences from developing Asia, Amsterdam: Elsevier Science.

Suryahadi, A., Sumarto, S. and Pritchett, L. (2003): Evolution of poverty during the crisis in Indonesia, Asian Economic Journal, 17(3): 221-241.

Suryahadi, A., Suryadarma, D. and Sumarto, S. (2009): The effects of location and sectoral components of economic growth on poverty: Evidence from Indonesia, Journal of Development Economics, 89(1): 109-117. 
Topalova, P. (2010): Factor immobility and regional impacts of trade liberalization: Evidence on Poverty from India, American Economic Journal: Applied Economics, 2(4): 1-41.

Wetterberg, A., Sumarto, S. and Pritchett, L. (1999): A national snapshot of the social impact of Indonesia's crisis, Bulletin of Indonesian Economic Studies, 35(3): 145-152.

Winters, L.A., McCulloch, N. and McKay, A. (2004): Trade liberalization and poverty: The evidence so far, Journal of Economic Literature, 42(1): 72-115.

WTO (1998): Trade Policy Review Indonesia, World Trade Organization, Geneva.

WTO (2001): Doha Ministerial Declaration, 4th session of the Ministerial Conference, World Trade Organization, Geneva, Available online at http://www.wto.org/english/thewto_e/minist_e/ min01_e/mindecl_e.htm. 
Tables

Table 1 Descriptive statistics

\begin{tabular}{lrrlrr}
\hline Variables & Mean & SD & Min & Max & No. obs. \\
Dependent var. & & & & & \\
PO & 0.2723 & 0.1736 & 0 & 0.8726 & 1036 \\
P1 & 0.0568 & 0.0494 & 0 & 0.3403 & 1036 \\
P2 & 0.0177 & 0.0194 & 0 & 0.1555 & 1036 \\
Formal sector & 0.2955 & 0.1533 & 0.0407 & 0.6893 & 777 \\
Activity & 0.5830 & 0.0739 & 0.4094 & 0.8191 & 1036 \\
Agriculture/mining & 0.4948 & 0.2522 & 0.0037 & 0.9074 & 1036 \\
Manufacturing & 0.0983 & 0.0766 & 0.0023 & 0.5525 & 1036 \\
Utilities & 0.0032 & 0.0037 & 0 & 0.0218 & 1036 \\
Construction & 0.0393 & 0.0242 & 0.0007 & 0.1877 & 1036 \\
Trade & 0.1736 & 0.0913 & 0.0138 & 0.4670 & 1036 \\
Transportation & 0.0421 & 0.0272 & 0.0016 & 0.1520 & 1036 \\
Financial services & 0.0065 & 0.0088 & 0 & 0.0786 & 1036 \\
Other services & 0.1422 & 0.0856 & 0.0248 & 0.4990 & 1036 \\
In Firm wage bill & 15.9102 & 2.4354 & 8.7806 & 22.1963 & 991 \\
In Total firm employment & 7.9432 & 2.0552 & 2.9957 & 12.9947 & 991 \\
In Hourly wage & 7.0960 & 0.4872 & 5.5213 & 8.1542 & 1036 \\
In Immigration & 9.9146 & 0.9964 & 7.3914 & 12.6431 & 203 \\
Skill intensity immigration & 0.5396 & 0.3023 & 0.0368 & 2.6044 & 203 \\
In Emigration & 10.1127 & 0.8617 & 7.5470 & 12.5040 & 203 \\
Skill intensity emigration & 0.6114 & 0.3568 & 0.0876 & 1.9583 & 203 \\
Explanatory var. & & & & & \\
Labour weighted tariffs & 17.1859 & 3.4828 & 0.3095 & 17.8596 & 1036 \\
Manuf. output weighted tariffs & 14.5944 & 6.8459 & 0 & 47.1813 & 1036 \\
Manuf. input weighted tariffs & 7.3058 & 3.5427 & 0 & 28.6421 & 1036 \\
Labour w. tariffs (w/o nontraded) & 12.2083 & 4.9927 & 3.5145 & 27.6609 & 1036 \\
Rural share & 0.6421 & 0.3166 & 0 & 1 & 1036 \\
Share of aged 16 to 60 & 0.6493 & 0.0416 & 0.5183 & 0.8137 & 1036 \\
Adult literacy rate (>20) & 0.8443 & 0.1071 & 0.3122 & 0.9988 & 1036 \\
Minimum wage & 0.4977 & 0.2575 & 0 & 0.9377 & 1036 \\
Initial share of agric. workers & 0.0126 & 0.0230 & 0 & 0.2169 & 1036 \\
Initial share of mining workers & 0.0996 & 0.07832 & 0 & 0.4410 & 1036 \\
Initial share of manuf. workers & & & & & \\
\hline
\end{tabular}


Table 2 Evolution of average effectively applied tariff rates by sector

\begin{tabular}{|c|c|c|c|c|}
\hline & 1993 & 1996 & 1999 & 2002 \\
\hline \multicolumn{5}{|l|}{ Agriculture } \\
\hline Plants and animals & 17.1 & 12.0 & 10.3 & 4.8 \\
\hline Forestry & 7.7 & 3.9 & 3.5 & 3.8 \\
\hline Hunting & 5.3 & 4.3 & 2.2 & 2.7 \\
\hline Sea fishery & 24.9 & 16.6 & 14.0 & 5.2 \\
\hline Fresh-water fishery & 10.0 & 0.0 & 0.0 & 0.0 \\
\hline \multicolumn{5}{|l|}{ Mining } \\
\hline Coal mining & 5.0 & 5.0 & 5.0 & 5.0 \\
\hline Metal ores mining & 3.3 & 3.2 & 3.5 & 2.8 \\
\hline Stones and sand mining & 7.0 & 5.6 & 3.6 & 3.5 \\
\hline Salt mining & 20.0 & 15.0 & 15.0 & 7.4 \\
\hline Minerals and chemicals mining & 2.9 & 3.0 & 3.0 & 2.7 \\
\hline Other mining & 4.0 & 3.4 & 3.6 & 3.6 \\
\hline \multicolumn{5}{|l|}{ Manufacturing } \\
\hline Food, beverages, tobacco & 23.4 & 18.1 & 17.1 & 12.6 \\
\hline Textiles, apparel, leather & 26.0 & 20.1 & 16.5 & 9.4 \\
\hline Wood and products & 30.0 & 16.6 & 14.1 & 7.7 \\
\hline Paper and products & 20.2 & 9.5 & 8.1 & 4.8 \\
\hline Chemicals and products & 11.9 & 9.4 & 8.7 & 6.1 \\
\hline Non-metallic mineral products & 20.4 & 9.5 & 7.0 & 5.6 \\
\hline Basic metals & 10.3 & 8.0 & 7.6 & 6.4 \\
\hline Metal products & 15.8 & 8.1 & 7.9 & 4.9 \\
\hline Other manufacturing & 32.0 & 18.9 & 18.4 & 9.6 \\
\hline
\end{tabular}

Note: Sectors are defined based on a concordance between tariff and census labour market data. Source: UNCTAD-TRAINS database. 
Table 3 Poverty, 1993-2002, labour weighted tariffs

\begin{tabular}{lcccc}
\hline & $(1)$ & $(2)$ & $(3)$ & $(4)$ \\
\hline P0 & $\mathbf{0 . 0 0 9 8 * *}$ & $\mathbf{0 . 0 0 9 8 * *}$ & 0.0055 & 0.0040 \\
s.e. & $(0.0033)$ & 0.0033 & 0.0070 & 0.0066 \\
p-value & 0.003 & 0.003 & 0.436 & 0.540 \\
\hline P1 & $\mathbf{0 . 0 0 4 1 ^ { * * }}$ & $\mathbf{0 . 0 0 4 1 ^ { * * }}$ & $\mathbf{0 . 0 0 5 6 ^ { * }}$ & $\mathbf{0 . 0 0 5 1 ^ { * }}$ \\
s.e. & 0.0011 & 0.0011 & 0.0025 & 0.0023 \\
p-value & 0.000 & 0.000 & 0.026 & 0.029 \\
\hline P2 & $\mathbf{0 . 0 0 1 7 ^ { * * }}$ & $\mathbf{0 . 0 0 1 7 ^ { * * }}$ & $\mathbf{0 . 0 0 2 7}$ & $\mathbf{0 . 0 0 2 5}$ \\
s.e. & 0.0005 & 0.0005 & 0.0011 & 0.0011 \\
p-value & 0.000 & 0.001 & 0.020 & 0.022 \\
\hline N & 777 & 777 & 777 & 777 \\
Year-island dummies & Yes & Yes & Yes & Yes \\
Time variant controls & No & Yes & Yes & Yes \\
Initial labour force and rural population shares & No & No & Yes & Yes \\
Dependent variable 1993 & No & No & No & Yes \\
\hline
\end{tabular}

Note: Each block of the table reports separate tariff coefficients, generated by first difference estimates of the reported dependent variables on tariffs and further controls. Time variant controls include first differences of the share of rural population, the share of working age population (1655), literacy rates at age 20-99 and minimum wage. Standard errors, clustered at the district level, are reported in parentheses. ${ }^{* *},{ }^{*},+$ mark statistical significance at the $1,5,10 \%$ level.

Table 4 Poverty by education level of the head of household, 1993-2002, labour weighted tariffs

\begin{tabular}{lccc}
\hline & $\begin{array}{c}\text { Max. primary } \\
\text { education }\end{array}$ & $\begin{array}{c}\text { Junior secondary } \\
\text { education }\end{array}$ & $\begin{array}{c}\text { Senior sec. or } \\
\text { higher education }\end{array}$ \\
\hline P0 & -0.0037 & 0.0051 & 0.0062 \\
s.e. & 0.0081 & 0.0093 & 0.0062 \\
p-value & 0.648 & 0.586 & 0.318 \\
\hline P1 & 0.0036 & $\mathbf{0 . 0 0 5 8}$ & 0.0012 \\
s.e. & 0.0029 & 0.0026 & 0.0014 \\
p-value & 0.202 & 0.027 & 0.416 \\
\hline P2 & 0.0021 & $\mathbf{0 . 0 0 2 5}$ & 0.0002 \\
s.e. & 0.0013 & 0.0010 & 0.0005 \\
p-value & 0.107 & 0.016 & 0.707 \\
\hline N & 777 & 777 & 777 \\
\hline
\end{tabular}

Note: Each block of the table reports separate tariff coefficients, generated by first difference estimates of the reported dependent variables on tariffs and further controls. Specification includes year-island dummy variables, time variant controls variables in first difference form (share of rural population, share of working age population (16-55), literacy rates at age 20-99, minimum wage), 1990 labour shares used for tariff weights and 1993 rural population shares. Standard errors, clustered at the district level, are reported in parentheses. $* *, *,+$ mark statistical significance at the 1, 5, 10\% level. 
Table 5 Labour market participation and formal sector employment, by education level of the head of household, labour weighted tariffs

\begin{tabular}{|c|c|c|c|c|}
\hline & All & $\begin{array}{c}\text { Max. primary } \\
\text { education }\end{array}$ & $\begin{array}{c}\text { Junior secondary } \\
\text { education }\end{array}$ & $\begin{array}{c}\text { Senior sec. or } \\
\text { higher education }\end{array}$ \\
\hline Time period & \multicolumn{4}{|c|}{$1993-1996$} \\
\hline Formal sector & $-0.0129 *$ & $-0.0127+$ & -0.0174 & 0.0032 \\
\hline s.e. & 0.0057 & 0.0065 & 0.0114 & 0.0110 \\
\hline $\mathrm{p}$-value & 0.026 & 0.052 & 0.128 & 0.771 \\
\hline $\mathrm{N}$ & 259 & 259 & 259 & 259 \\
\hline Time period & \multicolumn{4}{|c|}{ 1993-2002 } \\
\hline Activity & 0.0023 & 0.0024 & -0.0026 & 0.0019 \\
\hline s.e. & 0.0027 & 0.0032 & 0.0045 & 0.0037 \\
\hline $\mathrm{p}$-value & 0.409 & 0.465 & 0.573 & 0.618 \\
\hline $\mathrm{N}$ & 777 & 777 & 777 & 777 \\
\hline \multicolumn{5}{|c|}{$\begin{array}{l}\text { Note: Each block of the table reports separate tariff coefficients, generated by first difference } \\
\text { estimates of the reported dependent variables on tariffs and further controls. Specification includes } \\
\text { year-island dummy variables, time variant controls variables in first difference form (share of rura } \\
\text { population, share of working age population (16-55), literacy rates at age } 20-99 \text {, minimum wage) } \\
1990 \text { labour shares used for tariff weights and } 1993 \text { rural population shares. Standard errors } \\
\text { clustered at the district level, are reported in parentheses. }{ }^{* *},{ }^{*},+ \text { mark statistical significance at the } \\
1,5,10 \% \text { level. }\end{array}$} \\
\hline
\end{tabular}


Table 6 Sector of employment, by education level of the head of household, 1993-2002, labour weighted tariffs

\begin{tabular}{|c|c|c|c|c|}
\hline & All & $\begin{array}{l}\text { Max. primary } \\
\text { education }\end{array}$ & $\begin{array}{c}\text { Junior secondary } \\
\text { education }\end{array}$ & $\begin{array}{c}\text { Senior sec. or } \\
\text { higher education }\end{array}$ \\
\hline Agriculture/mining & -0.0004 & 0.0028 & -0.0078 & 0.0032 \\
\hline s.e. & 0.0033 & 0.0032 & 0.0060 & 0.0044 \\
\hline$p$-value & 0.911 & 0.384 & 0.195 & 0.473 \\
\hline Manufacturing & 0.0002 & 0.0005 & 0.0008 & -0.0000 \\
\hline s.e. & 0.0025 & 0.0026 & 0.0044 & 0.0038 \\
\hline$p$-value & 0.924 & 0.857 & 0.855 & 0.992 \\
\hline Utilities & $0.0007^{*}$ & -0.0000 & 0.0004 & $0.0013+$ \\
\hline s.e. & 0.0003 & 0.0003 & 0.0006 & 0.0008 \\
\hline$p$-value & 0.020 & 0.850 & 0.540 & 0.076 \\
\hline Construction & $0.0043^{*}$ & $0.0064 * *$ & 0.0046 & 0.0014 \\
\hline s.e. & 0.0020 & 0.0023 & 0.0031 & 0.0023 \\
\hline$p$-value & 0.033 & 0.006 & 0.133 & 0.535 \\
\hline Trade & $-0.0058 *$ & $-0.0092 * *$ & -0.0003 & 0.0005 \\
\hline s.e. & 0.0026 & 0.0035 & 0.0047 & 0.0041 \\
\hline$p$-value & 0.026 & 0.009 & 0.942 & 0.907 \\
\hline Transportation & 0.0019 & 0.0011 & $0.0077^{*}$ & 0.0031 \\
\hline s.e. & 0.0012 & 0.0017 & 0.0030 & 0.0021 \\
\hline$p$-value & 0.112 & 0.510 & 0.012 & 0.143 \\
\hline Financial services & $-0.0013 * *$ & $-0.0010 * *$ & -0.0006 & $-0.0023+$ \\
\hline s.e. & 0.0005 & 0.0003 & 0.0007 & 0.0014 \\
\hline$p$-value & 0.006 & 0.005 & 0.342 & 0.098 \\
\hline Other services & 0.0003 & -0.0006 & -0.0046 & -0.0071 \\
\hline s.e. & 0.0030 & 0.0028 & 0.0046 & 0.0064 \\
\hline$p$-value & 0.931 & 0.832 & 0.314 & 0.263 \\
\hline $\mathrm{N}$ & 777 & 777 & 777 & 777 \\
\hline
\end{tabular}

Note: Each block of the table reports separate tariff coefficients, generated by first difference estimates of the reported dependent variables on tariffs and further controls. Specification includes year-island dummy variables, time variant controls variables in first difference form (share of rural population, share of working age population (16-55), literacy rates at age 20-99, minimum wage), 1990 labour shares used for tariff weights and 1993 rural population shares. Standard errors, clustered at the district level, are reported in parentheses. $* *, *,+$ mark statistical significance at the $1,5,10 \%$ level. 
Table 7 Wage bill, total employment and hourly wages, by education level of the head of household, 1993-2002, tariffs weighted by manufacturing output

\begin{tabular}{lccc}
\hline & $\begin{array}{c}\text { Input weighted } \\
\text { tariffs }\end{array}$ & $\begin{array}{c}\text { Output weighted } \\
\text { tariffs }\end{array}$ & $\mathrm{N}$ \\
\hline Ln firm wage bill & $-\mathbf{0 . 0 8 2 0 *}$ & -0.0162 & 734 \\
s.e. & 0.0323 & 0.0145 & \\
p-value & 0.012 & 0.264 & 734 \\
\hline Ln total firm employment & $-\mathbf{0 . 0 4 7 4 +}$ & -0.0044 & \\
s.e. & 0.0267 & 0.0123 & \\
p-value & 0.077 & 0.725 & 777 \\
\hline Ln hourly wage (provincial average) & & & \\
\hline Full sample & $-0.0243+$ & 0.0014 & 777 \\
s.e. & 0.0118 & 0.0036 & \\
p-value & 0.052 & 0.711 & \\
\hline Maximum primary education & -0.0179 & 0.0011 & \\
s.e. & 0.0110 & 0.0040 & \\
p-value & 0.119 & 0.786 & \\
\hline Junior secondary education & $-0.0188^{*}$ & -0.0019 & \\
s.e. & 0.0101 & 0.0038 & \\
p-value & 0.077 & 0.628 & \\
\hline Senior secondary or higher education & -0.0115 & 0.0009 & \\
s.e. & 0.0072 & 0.0031 & \\
p-value & 0.123 & 0.768 & \\
\hline
\end{tabular}

Note: Each block of the table reports separate tariff coefficients, generated by first difference estimates of the reported dependent variables on tariffs and further controls. Specification includes year-island dummy variables, time variant controls variables in first difference form (share of rural population, share of working age population (16-55), literacy rates at age 20-99, minimum wage), 1990 labour shares used for tariff weights and 1993 rural population shares. Standard errors, clustered at the district level, are reported in parentheses. ${ }^{* *},{ }^{*},+$ mark statistical significance at the $1,5,10 \%$ level. 
Table 8 Placebo test on poverty regressed on future tariff changes, labour weighted tariffs

\begin{tabular}{lcccc}
\hline & $(1)$ & $(2)$ & $(3)$ & $(4)$ \\
\hline $\mathrm{P}_{0}$ & 0.0053 & 0.0014 & -0.0047 & -0.0080 \\
s.e. & 0.0036 & 0.0040 & 0.0082 & 0.0083 \\
$\mathrm{p}$-value & 0.146 & 0.721 & 0.569 & 0.337 \\
\hline $\mathrm{P}_{1}$ s.e. & -0.0001 & -0.0014 & -0.0029 & -0.0037 \\
$\mathrm{p}$-value & 0.0014 & 0.0014 & 0.0027 & 0.0027 \\
\hline $\mathrm{P}_{2}$ & 0.951 & 0.314 & 0.289 & 0.175 \\
s.e. & -0.0002 & -0.0008 & -0.0010 & -0.0013 \\
$\mathrm{p}$-value & 0.0007 & 0.0007 & 0.0012 & 0.0012 \\
$\mathrm{~N}$ & 0.776 & 0.228 & 0.402 & 0.281 \\
Year dummies & 518 & 518 & 518 & 518 \\
Time variant controls and year-island dummies & Yes & Yes & Yes & Yes \\
Initial labour force and rural population shares & No & Yes & Yes & Yes \\
Dependent variable 1993 & No & No & Yes & Yes \\
\hline Not Each bock of the table reports separate & No & Yes \\
\hline
\end{tabular}

Note: Each block of the table reports separate tariff coefficients, generated by first difference estimates of the reported dependent variables on tariffs and further controls. Standard errors, clustered at the district level, are reported in parentheses. $* *, *,+$ mark statistical significance at the $1,5,10 \%$ level.

Table 9 Poverty, 1993-2002, labour weighted tariffs, sensitivity to excluding non-tradable sectors from the weighting scheme

\begin{tabular}{lccc}
\hline $\begin{array}{l}\text { Tariff weights } \\
\text { based on: }\end{array}$ & $\begin{array}{c}\text { Tradable and non- } \\
\text { tradable sectors }\end{array}$ & \multicolumn{2}{c}{ Only tradable sectors } \\
Sample & All districts & All districts & $\begin{array}{c}\text { Districts with } 1990 \text { non- } \\
\text { tradable sector }<33 \%\end{array}$ \\
\hline P0 & 0.0055 & -0.0066 & 0.0146 \\
s.e. & 0.0070 & 0.0045 & 0.0136 \\
p-value & 0.436 & 0.144 & 0.286 \\
\hline P1 & $\mathbf{0 . 0 0 5 6 *}$ & -0.0007 & $\mathbf{0 . 0 0 8 1 +}$ \\
s.e. & 0.0025 & 0.0012 & 0.0046 \\
p-value & 0.026 & 0.569 & 0.080 \\
\hline P2 & $\mathbf{0 . 0 0 2 7 *}$ & 0.0000 & $\mathbf{0 . 0 0 3 7 +}$ \\
s.e. & 0.0011 & 0.0005 & 0.0020 \\
p-value & 0.020 & 0.919 & 0.068 \\
\hline $\mathrm{N}$ & 777 & 777 & 396 \\
\hline
\end{tabular}

Note: Each block of the table reports separate tariff coefficients, generated by first difference estimates of the reported dependent variables on tariffs and further controls. Specification includes year-island dummy variables, time variant controls variables in first difference form (share of rural population, share of working age population (16-55), literacy rates at age 20-99, minimum wage), 1990 labour shares used for tariff weights and 1993 rural population shares. Standard errors, clustered at the district level, are reported in parentheses. ${ }^{* *},{ }^{*},+$ mark statistical significance at the $1,5,10 \%$ level. 
Table 10 Poverty, employment and wages by time period

\begin{tabular}{|c|c|c|c|}
\hline Time period & 1993-2002 & 1993-1996 & $1999-2002$ \\
\hline \multicolumn{4}{|l|}{ Panel A } \\
\hline Tariff measure & \multicolumn{3}{|c|}{ Weighted by labour shares } \\
\hline PO & 0.0055 & -0.0129 & -0.0046 \\
\hline s.e. & 0.0070 & 0.0127 & 0.0164 \\
\hline$p$-value & 0.436 & 0.309 & 0.780 \\
\hline P1 & $0.0056^{*}$ & -0.0027 & 0.0057 \\
\hline s.e. & 0.0025 & 0.0036 & 0.0053 \\
\hline$p$-value & 0.026 & 0.459 & 0.280 \\
\hline P2 & $0.0027^{*}$ & -0.0011 & 0.0036 \\
\hline s.e. & 0.0011 & 0.0015 & 0.0022 \\
\hline$p$-value & 0.020 & 0.471 & 0.102 \\
\hline $\mathrm{N}$ & 777 & 259 & 259 \\
\hline \multicolumn{4}{|l|}{ Panel B } \\
\hline Tariff measure & \multicolumn{3}{|c|}{ Weighted by manufacturing input shares } \\
\hline Ln firm wage bill & $-0.0820 *$ & $-0.0788 *$ & $-0.1426^{*}$ \\
\hline s.e. & 0.0323 & 0.0351 & 0.0618 \\
\hline$p$-value & 0.012 & 0.026 & 0.022 \\
\hline Ln total firm employment & $-0.0474+$ & $-0.0587^{*}$ & -0.0758 \\
\hline s.e. & 0.0267 & 0.0290 & 0.0581 \\
\hline$p$-value & 0.077 & 0.044 & 0.193 \\
\hline $\mathrm{N}$ & 734 & 247 & 240 \\
\hline \multicolumn{4}{|l|}{ Panel C } \\
\hline Dependent & \multirow{2}{*}{\multicolumn{3}{|c|}{$\begin{array}{l}\text { Ln hourly wage (provincial average) } \\
\text { Weighted by manufacturing input shares }\end{array}$}} \\
\hline Tariff measure & & & \\
\hline Full sample & $-0.0243+$ & $-0.0138 *$ & $-0.0513^{*}$ \\
\hline s.e. & 0.0118 & 0.0062 & 0.0204 \\
\hline$p$-value & 0.052 & 0.026 & 0.013 \\
\hline Max. primary education & -0.0179 & -0.0102 & $-0.0496 *$ \\
\hline s.e. & 0.0110 & 0.0065 & 0.0194 \\
\hline$p$-value & 0.119 & 0.117 & 0.011 \\
\hline Junior secondary education & $-0.0188^{*}$ & $-0.0220 *$ & -0.0251 \\
\hline s.e. & 0.0101 & 0.0085 & 0.0176 \\
\hline$p$-value & 0.077 & 0.010 & 0.154 \\
\hline Senior sec. ed. or higher & -0.0115 & -0.0055 & -0.0217 \\
\hline s.e. & 0.0072 & 0.0082 & 0.0154 \\
\hline$p$-value & 0.123 & 0.505 & 0.158 \\
\hline $\mathrm{N}$ & 777 & 259 & 259 \\
\hline
\end{tabular}

Note: Each block of the table reports separate tariff coefficients, generated by first difference estimates of the reported dependent variables on tariffs and further controls. Specifications replicate those of column (3) of Table $\mathbf{3}$ (Panel A), and column 1 of Table $\mathbf{7}$ (Panel B and C) for the full time period and for the first and last time periods. Standard errors, clustered at the district level in panels $\mathrm{A}$ and $\mathrm{B}$ and at the province level in panel $\mathrm{C}$, are reported in parentheses. ${ }^{* *},{ }^{*},+$ mark statistical significance at the $1,5,10 \%$ level. 
Table 11 Domestic migration flows, 1990-1995, labour weighted tariffs, by individual education level

\begin{tabular}{lcc}
\hline & Immigration & Emigration \\
\hline Overall & $-\mathbf{0 . 2 1 4 4 *}$ & -0.0874 \\
s.e. & 0.1059 & 0.0939 \\
p-value & 0.044 & 0.353 \\
\hline Primary or less & $-\mathbf{0 . 2 6 0 6 *}$ & -0.0548 \\
s.e. & 0.1087 & 0.1042 \\
p-value & 0.018 & 0.600 \\
\hline Jun. secondary or more & -0.0983 & -0.1565 \\
s.e. & 0.1434 & 0.1397 \\
p-value & 0.494 & 0.264 \\
\hline Skill intensity & 0.0695 & -0.0458 \\
s.e. & 0.0606 & 0.0851 \\
p-value & 0.253 & 0.591 \\
\hline $\mathrm{N}$ & 203 & 203
\end{tabular}

Each block of the table reports separate tariff coefficients, generated by regressing migration flows of the reported groups on changes in tariffs and further controls in the form of province fixed effects, district population size, and initial sectoral labour market shares. Robust standard errors are reported in parentheses. $* *, *,+$ mark statistical significance at the $1,5,10 \%$ level. 


\section{Figures}

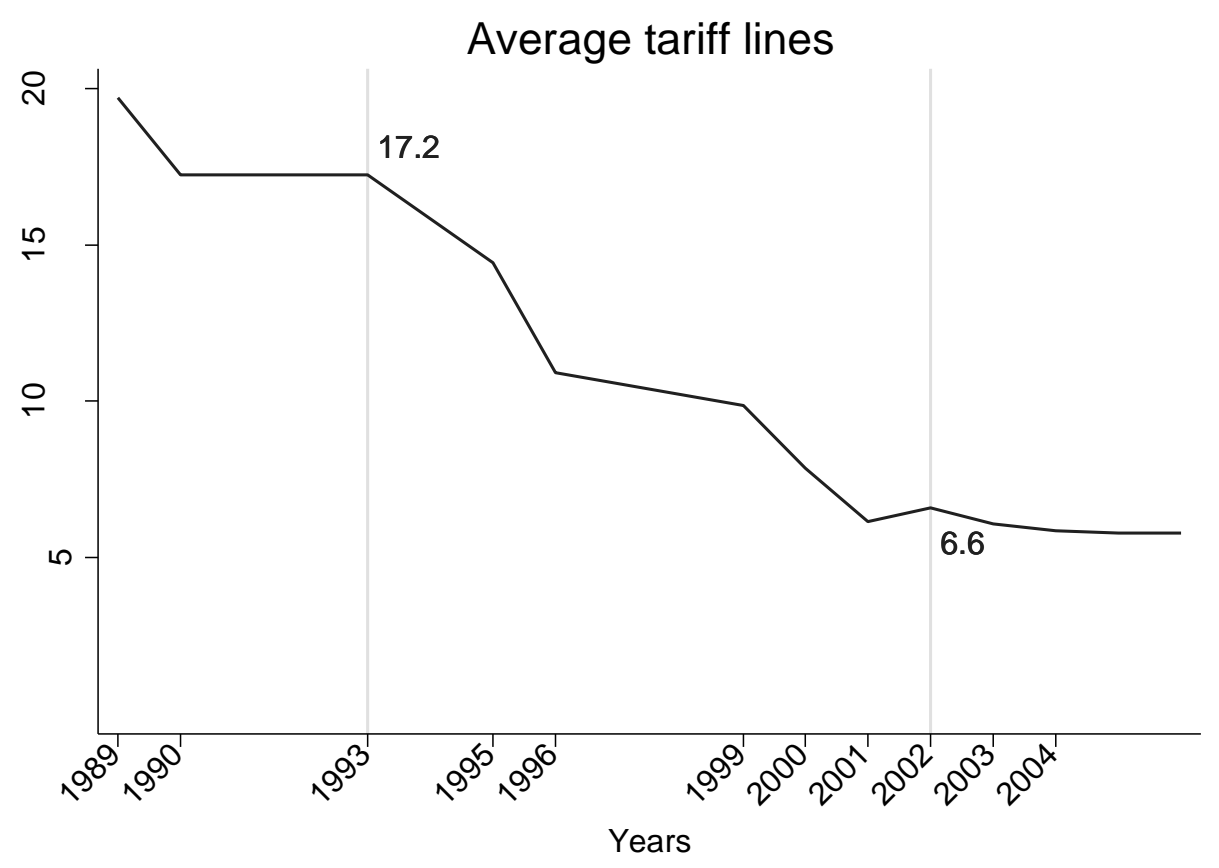

Figure 1 Evolution of average tariff lines 1993-2002, source: Kis-Katos and Sparrow (2011)
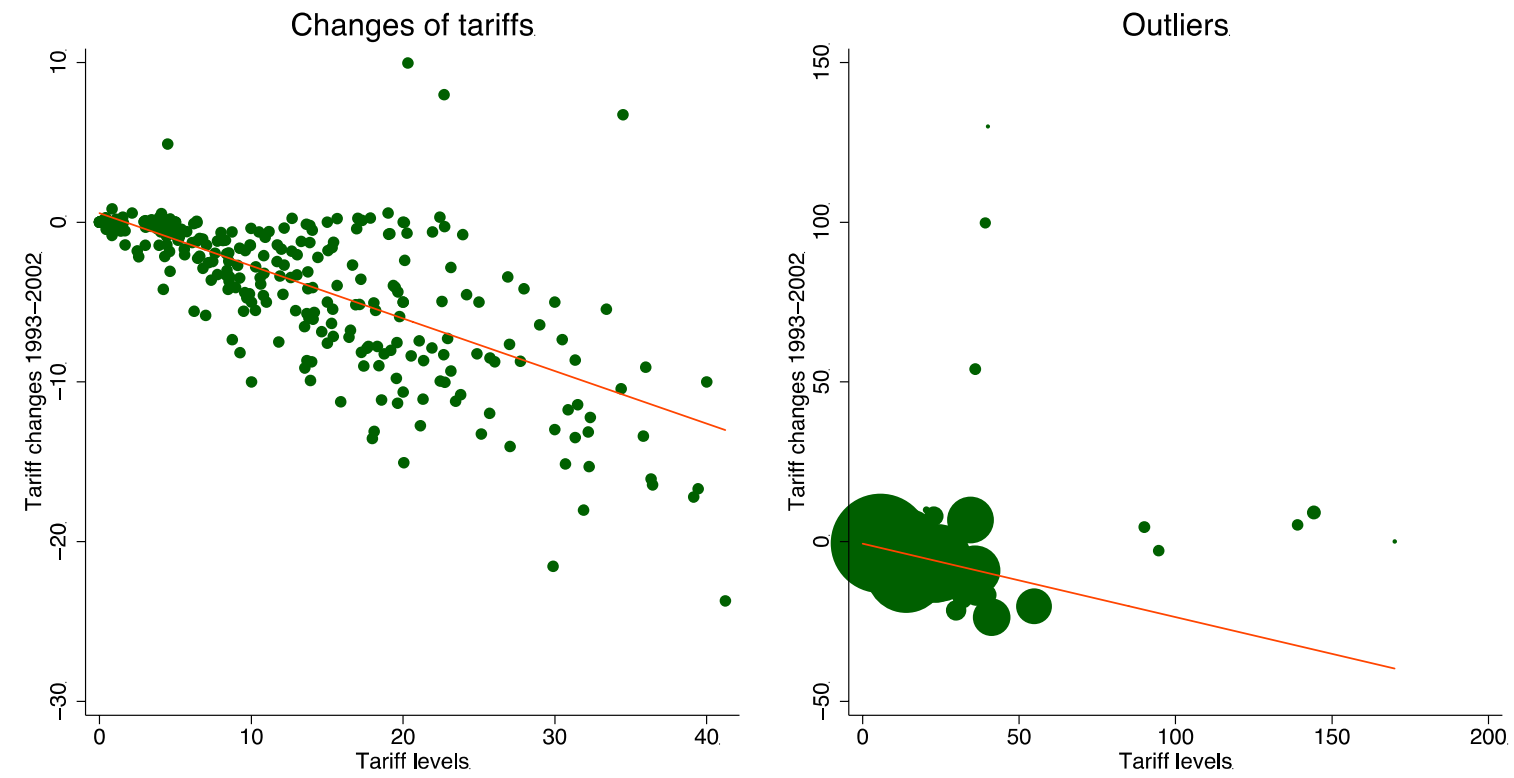

Figure 2 Relative tariff changes related to initial tariff levels (1993-2002), source: Kis-Katos and Sparrow (2011) 


\section{Supplemental appendix}

Table A1. Descriptive statistics of dependent variables by education category

\begin{tabular}{lccc}
\hline Variable & $\begin{array}{c}\text { Max. primary } \\
\text { education }\end{array}$ & $\begin{array}{c}\text { Junior sec. } \\
\text { education }\end{array}$ & $\begin{array}{c}\text { Senior sec. or } \\
\text { higher education }\end{array}$ \\
\cline { 2 - 4 } P0 & $0.3184(0.1839)$ & $0.1902(0.1424)$ & $0.0966(0.0917)$ \\
P1 & $0.0673(0.0548)$ & $0.0358(0.0372)$ & $0.0160(0.0199)$ \\
P2 & $0.0212(0.0220)$ & $0.0103(0.0141)$ & $0.0043(0.0069)$ \\
Formal sector & $0.2114(0.1357)$ & $0.3197(0.1502)$ & $0.5759(0.1035)$ \\
Activity & $0.5375(0.1033)$ & $0.5469(0.0941)$ & $0.7841(0.0678)$ \\
Agriculture/mining & $0.5754(0.2651)$ & $0.3864(0.2471)$ & $0.1817(0.1349)$ \\
Manufacturing & $0.0898(0.0683)$ & $0.1296(0.1091)$ & $0.1000(0.0948)$ \\
Utilities & $0.0013(0.0021)$ & $0.0035(0.0058)$ & $0.0085(0.0092)$ \\
Construction & $0.0409(0.0317)$ & $0.0531(0.0359)$ & $0.0346(0.0209)$ \\
Trade & $0.1763(0.1126)$ & $0.2206(0.1041)$ & $0.1720(0.0787)$ \\
Transportation & $0.0393(0.0325)$ & $0.0666(0.0410)$ & $0.0451(0.0262)$ \\
Financial services & $0.0013(0.0031)$ & $0.0047(0.0072)$ & $0.0213(0.0192)$ \\
Other services & $0.0756(0.0780)$ & $0.1354(0.0757)$ & $0.4367(0.1147)$ \\
In Hourly wage & $6.8013(0.4415)$ & $6.9824(0.3867)$ & $7.2615(0.6345)$ \\
In Immigration & $9.4992(1.0209)$ & $8.7417(1.0585)$ \\
In Emigration & $9.6573(0.9098)$ & $9.0027(0.9200)$ \\
\hline
\end{tabular}

Note: Cells of the table present means and standard deviations (in parentheses) for the various dependent variables. Education categories refer to household heads, except for log hourly wages, where education refers to individual workers. The number of observation is 1036 in all cells, except for Formal sector ( $N=777$ ) and for In Immigration/Emigration ( $N=203)$. 
Table A2. Full specification for estimates of Table 3

\begin{tabular}{lccc}
\hline Dependent & $\Delta \mathrm{P} 0$ & $\Delta \mathrm{P} 1$ & $\Delta \mathrm{P} 2$ \\
& $(1)$ & $(2)$ & $(3)$ \\
\cline { 2 - 4 }$\Delta$ Labour weighted tariff & 0.0055 & $0.0056^{*}$ & $0.0027^{*}$ \\
& $(0.0070)$ & $(0.0025)$ & $(0.0011)$ \\
$\Delta$ Rural share & 0.0877 & 0.0198 & 0.0068 \\
& $(0.0734)$ & $(0.0216)$ & $(0.0084)$ \\
$\Delta$ Share of aged 16-60 & -0.2471 & -0.0252 & 0.0106 \\
& $(0.1975)$ & $(0.0690)$ & $(0.0310)$ \\
$\Delta$ Adult literacy rate $(>20)$ & -0.1068 & -0.0224 & -0.0077 \\
& $(0.1482)$ & $(0.0469)$ & $(0.0196)$ \\
$\Delta$ Minimum wage & 0.00005 & 0.0001 & 0.0001 \\
& $(0.0010)$ & $(0.0003)$ & $(0.0001)$ \\
Initial share of agric. workers & -0.0039 & 0.0158 & 0.0086 \\
& $(0.0353)$ & $(0.0121)$ & $(0.0054)$ \\
Initial share of mining workers & -0.0202 & -0.0051 & -0.0010 \\
& $(0.0727)$ & $(0.0198)$ & $(0.0073)$ \\
Initial share of manuf. workers & 0.0154 & $0.0380^{*}$ & $0.0181 *$ \\
& $(0.0522)$ & $(0.0176)$ & $(0.0078)$ \\
Initial rural share & -0.0145 & -0.0064 & -0.0027 \\
& $(0.0169)$ & $(0.0054)$ & $(0.0022)$ \\
Year-island dummies & $Y e s$ & $Y e s$ & $Y e s$ \\
$\mathrm{~N}$ & 777 & 777 & 777 \\
R2 & 0.517 & 0.415 & 0.322 \\
\hline NOte: The table & & & \\
\hline
\end{tabular}

Note: The table reports the full results of column (3) of Table $\mathbf{3}$ from first difference estimates. Standard errors, clustered at the district level, are reported in parentheses. ${ }^{* *},{ }^{*},+$ mark statistical significance at the $1,5,10 \%$ level. 